\title{
Adsorption and Corrosion Inhibition Behavior of C38 Steel by one Derivative of Quinoxaline in $1 \mathrm{M} \mathrm{HCl}$
}

\author{
M. Elayyachy, B. Hammouti, A. EI Idrissi and A. Aouniti \\ LCAE-URAC18, Faculté des Sciences, Université Mohammed Premier, \\ B.P. 717, 60000 Oujda, Morocco
}

Received 15 November 2010; accepted 28 February 2011

\begin{abstract}
The influence of 2-[3-(2-oxo-2-phenylethylidene)-1,4-dihydroquinoxaline-2(1H)ylidene]-1-phenylethanone (Qx1) and amino-2-aniline (Diam1) on the corrosion of steel in $1 \mathrm{M} \mathrm{HCl}$ solution has been investigated by weight loss measurements, potentiodynamic polarisation and impedance spectroscopy (EIS) methods. The inhibiting action increases with the concentration of Qx1 and Diam1. The highest efficiency $(85 \%)$ is obtained at the $10^{-4} \mathrm{M}$ Qx1. There is good agreement between gravimetric and electrochemical methods (potentiodynamic polarisation and EIS). Polarisation measurements also show that Qx1 and Diam1 act as mixed inhibitors. The cathodic curves indicate that the reduction of proton at the steel surface happens with an activating mechanism. Qx1 adsorbs on the steel surface according to Langmuir adsorption model. Effect of temperature is also studied between 308 and $353 \mathrm{~K}$.
\end{abstract}

Keywords: quinoxaline, inhibition, corrosion, steel, acid.

\section{Introduction}

Addition of inhibitor remains the necessary procedure to secure the metal against acid attack in chemical cleaning and pickling to remove mill scales (oxide scales) from the metallic surface. Inhibitors should be effective even under severe conditions in concentrated hydrochloric acid (20\%) at temperatures up to $60{ }^{\circ} \mathrm{C}$. Organic compounds rich in heteroatoms such as sulphur, nitrogen and oxygen generally exhibit the best protection for corrosion. Among these inhibitors, diamines [1-4] are efficient ones in corrosive media. Their adsorption is generally explained by the formation of an adsorptive film of a physical and/or chemical character on the metal surface. The synthesis of new organic molecules

\footnotetext{
*Corresponding author. E-mail address: hammoutib@gmail.com
} 
offers various molecular structures containing several heteroatoms and substituents. Our research in these latest decennia has permitted us to classify several series such of compounds namely aminoacid and aminoester [5-11], pyrazole [12-18], and pyridine [19-23] as effective corrosion inhibitors. The continuation of our work on development of organic compounds as acid inhibitors is oriented to a new series of quinoxaline compounds. The good inhibitory effect of quinoxaline derivatives [24-27] has incited us to test another quinoxaline derivative: 2-[3-(2-oxo-2-phenylethylidene)-1,4-dihydroquinoxaline2(1H)-ylidene]-1-phenyl ethanone (Qx1) as corrosion inhibitor for steel in $1 \mathrm{M}$ $\mathrm{HCl}$ in the 308-353 $\mathrm{K}$ range. The quinoxaline ring is part of many polycyclic compounds of biological or industrial significance. The anti-tuberculotic, anticancer activities, anti-mycobacterial, anti-trichomonas and anti-candida data of quinoxaline derivatives have been reported [28-31].

The objective of the present work therefore is to study the mechanism of corrosion inhibition of the newly synthesized quinoxaline derivative and its reactant diamine on steel surface (Scheme 1). The behaviour of 2-[3-(2-oxo-2phenylethylidene)-1,4-dihydroquinoxaline-2(1H)-ylidene]-1-phenylethanone (Qx1) and amino-2-aniline (Diam1) as a corrosion inhibitor for metals is reported using the weight loss method, potentiodynamic polarization and electrochemical impedance spectroscopy (EIS).

\section{Experimental}

\section{Inhibitors}

The quinoxaline compound (Qx1) was synthesised from amino-2-aniline (Diam1) and 1,6-dihydroxy-1,6-diphenylhexa-1,5-diene-3,4-dione (R1), according to scheme 1 . It was purified and characterised by N.M.R. and I.R. spectroscopies and element analysis before use. All chemicals used were analytical grade and the solvents were distilled before use. We notice also that $\mathrm{R} 1$ is an insoluble compound in acid solution. The molecular structure of Qx1 is shown in scheme 1.

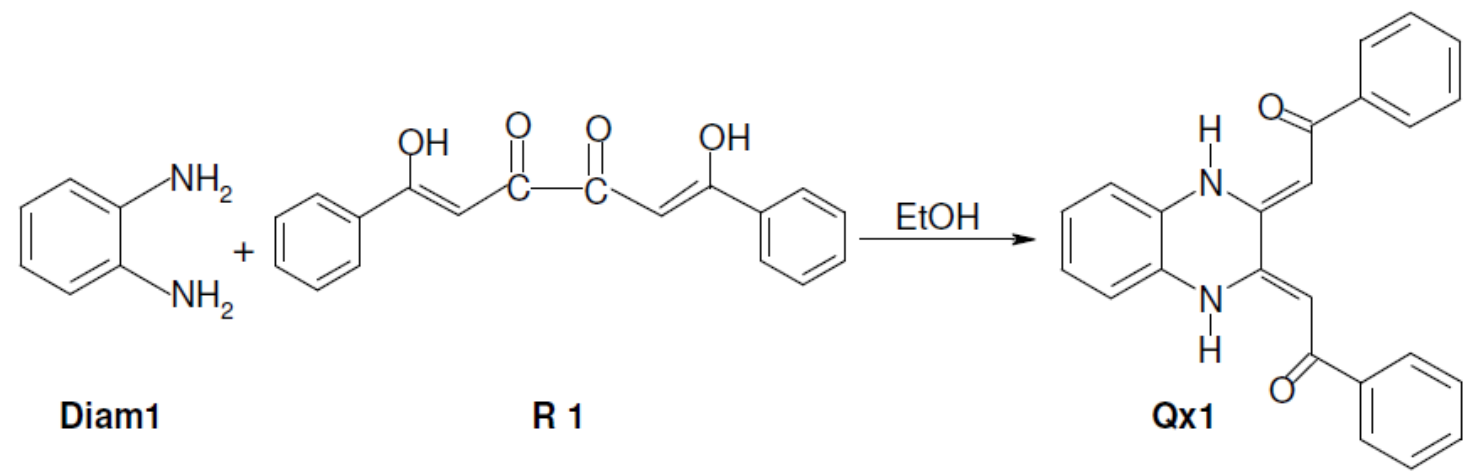

Diam1: amino-2-aniline; R1 : 1,6-dihydroxy-1,6-diphenylhexa-1,5-diene-3,4-dione; Qx1: 2-[3(2-oxo-2-phenylethylidene)-1,4-dihydroquinoxaline-2(1H)-ylidene]-1-phenylethanone

Scheme 1. Molecular structure of the quinoxaline derivative. 


\section{Gravimetric, polarisation and impedance spectroscopy measurements}

Prior to all measurements, the steel specimens $(0.09 \% \mathrm{P} ; 0.38 \% \mathrm{Si} ; 0.01 \% \mathrm{Al}$; $0.05 \% \mathrm{Mn} ; 0.21 \% \mathrm{C} ; 0.05 \% \mathrm{~S}$; Fe balance) were abraded with different emery paper up to 1000 grade, washed thoroughly with bidistilled water, degreased and dried with acetone. The aggressive solution $(1 \mathrm{M} \mathrm{HCl})$ was prepared by dilution of analytical grade $37 \% \mathrm{HCl}$ with bidistilled water.

Gravimetric measurements were carried out in a double walled glass cell equipped with a thermostat-cooling condenser. The solution volume was 100 $\mathrm{cm}^{3}$. The steel specimens used had a rectangular form $(2 \mathrm{~cm} \mathrm{x} 2 \mathrm{~cm} \times 0.05 \mathrm{~cm})$. Electrochemical measurements were carried out in a conventional three electrode electrolysis cylindrical pyrex glass cell. The working electrode (W.E.) had the form of a disc cut from the steel sheet. The area exposed to the corrosive solution was $1 \mathrm{~cm}^{2}$. A saturated calomel electrode (SCE) and a disc platinum electrode were used respectively as reference and auxiliary electrodes. The temperature was thermostatically controlled at $308 \pm 1 \mathrm{~K}$.

Polarisation curves were recorded with a potentiostat (Amel 549) using a linear sweep generator (Amel 567) at a scan rate of $0.33 \mathrm{mV} / \mathrm{s}$. Before recording the polarisation curves, the test solution was de-aerated and magnetically stirred for $30 \mathrm{~min}$ in the cell with nitrogen. The steel electrode, kept at its open circuit value, was polarised at $-800 \mathrm{mV}$ for $10 \mathrm{~min}$. The potential of the electrode was then swept. Gas bubbling was maintained throughout the experiments.

Electrochemical impedance spectroscopy (EIS) was carried out with a Tacussel electrochemical system at $\mathrm{E}_{\mathrm{corr}}$ after immersion in solution without bubbling, the circular surface of steel exposing of $1 \mathrm{~cm}^{2}$ to the solution was used as working electrode. After the determination of steady-state current at a given potential, sine wave voltage $(10 \mathrm{mV})$ peak to peak, at frequencies between $100 \mathrm{kHz}$ and 10 $\mathrm{mHz}$ were superimposed on the rest potential. Computer programs automatically controlled the measurements performed at rest potentials after $30 \mathrm{~min}$ of exposure. The impedance diagrams are given in the Nyquist representation.

\section{Results and discussion \\ Weight loss tests}

The effect of addition of quinoxaline and diamine compounds tested at different concentrations on the corrosion of steel in $1 \mathrm{M} \mathrm{HCl}$ solution was studied by weight-loss method at $308 \mathrm{~K}$ after 6 hours of immersion. Inhibition efficiency $\left(\mathrm{E}_{\mathrm{w}} \%\right)$ is calculated as follows (equation below):

$$
\mathrm{E}_{\mathrm{w}} \%=\left(1-\frac{\mathrm{W}_{\text {corr }}}{\mathrm{W}_{\text {corr }}^{\mathrm{o}}}\right) \cdot 100
$$

where $\mathrm{W}_{\text {corr }}$ and $\mathrm{W}^{\circ}$ corr are the corrosion rates of steel with and without organic compound, respectively.

Table 1 shows the results of weight loss of steel in $1 \mathrm{M} \mathrm{HCl}$ with and without the addition of various concentrations of Qx1 and Diam1. It is clear that the corrosion rate decreases with the concentration of the compounds tested. Qx1 shows a higher inhibitory power compared to Diam1 The inhibition efficiency, $\mathrm{E} \%$, attains $81 \%$ and $50 \%$ at $10^{-4} \mathrm{M}$, respectively. 
The protective properties of $\mathrm{Qx} 1$ are probably due to the interaction between $\pi$ electrons of the three aromatic rings of the quinoxaline and the free pairs of electrons of $\mathrm{N}$ and $\mathrm{O}$ atoms with the positively charged steel surface.

Table 1. Effect of Qx1 and Diam1 concentration on corrosion of steel in $1 \mathrm{M} \mathrm{HCl}(308$ $\mathrm{K}$ and $6 \mathrm{~h}$ ).

\begin{tabular}{|c|c|c|c|}
\hline & $\begin{array}{c}\text { Concentration } \\
(\mathrm{M})\end{array}$ & $\begin{array}{c}\text { Corrosion rate } \\
\mathrm{W}\left(\mathrm{mg}^{-2} \mathrm{~cm}^{-2} \cdot \mathrm{h}^{-1}\right)\end{array}$ & $\begin{array}{c}\text { Efficiency } \\
\left(\mathrm{E}_{\mathrm{w}} \%\right)\end{array}$ \\
\hline $\mathrm{HCl}$ & 1 & 0.661 & - \\
\hline \multirow{5}{*}{ Qx1 } & $10^{-4}$ & 0.124 & 81 \\
\cline { 2 - 4 } & $5 \times 10^{-5}$ & 0.184 & 72 \\
\cline { 2 - 4 } & $10^{-5}$ & 0.234 & 65 \\
\cline { 2 - 4 } & $5 \times 10^{-6}$ & 0.338 & 49 \\
\cline { 2 - 4 } & $10^{-6}$ & 0.400 & 39 \\
\hline \multirow{5}{*}{ Diam1 } & $10^{-7}$ & 0.479 & 27 \\
\cline { 2 - 4 } & $10^{-3}$ & 0.174 & 74 \\
\cline { 2 - 4 } & $5 \times 10^{-4}$ & 0.297 & 55 \\
\cline { 2 - 4 } & $10^{-4}$ & 0.333 & 50 \\
\cline { 2 - 4 } & $5 \times 10^{-5}$ & 0.363 & 45 \\
\cline { 2 - 4 } & $10^{-5}$ & 0.407 & 38 \\
\hline
\end{tabular}

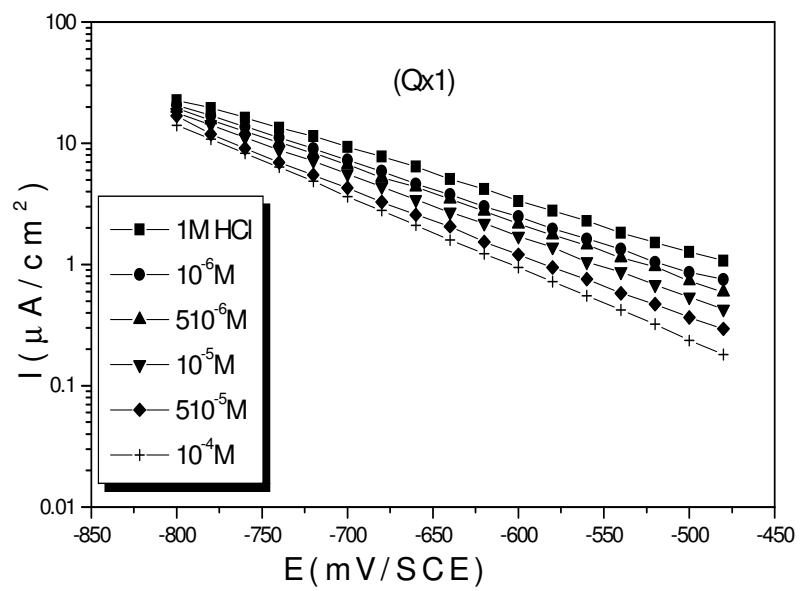

Figure 1. Polarisation curves of steel in $1 \mathrm{M} \mathrm{HCl}$ for various concentrations of Qx1.

\section{Polarisation results}

The influence of concentration of Qx1 and Diam1 on the cathodic polarisation curves of steel in $1 \mathrm{M} \mathrm{HCl}$ is studied at $298 \mathrm{~K}$. Fig. 1 shows the typical curves obtained by $\mathrm{Qx} 1$ addition. Table 2 gives values of corrosion current $\left(\mathrm{I}_{\text {corr }}\right)$, corrosion potential $\left(\mathrm{E}_{\text {corr }}\right)$, and cathodic Tafel slope $\left(\mathrm{b}_{\mathrm{c}}\right)$. In this case, the relation below (equation 2 ) determines the inhibition efficiency $\left(\mathrm{E}_{\mathrm{I}} \%\right)$ : 


$$
\mathrm{E}_{\mathrm{I}} \%=\left(1-\frac{\mathrm{I}_{\text {corr }}}{\mathrm{I}_{\text {corr }}^{\mathrm{o}}}\right) \cdot 100
$$

where $\mathrm{I}^{\circ}$ corr and $\mathrm{I}_{\text {corr }}$ are the uninhibited and inhibited corrosion current densities, respectively, determined by extrapolation of cathodic Tafel lines to corrosion potential.

Table 2. Electrochemical parameters of steel in $1 \mathrm{M} \mathrm{HCl}+$ Diam1 and Qx1 at various concentrations, and the corresponding inhibition efficiency.

\begin{tabular}{|c|c|c|c|c|c|}
\hline & $\begin{array}{c}\text { Concentration } \\
(\mathrm{M})\end{array}$ & $\begin{array}{c}\mathrm{E}_{\mathrm{corr}} \\
(\mathrm{mV} / \mathrm{SCE})\end{array}$ & $\begin{array}{c}\mathrm{b}_{\mathrm{c}} \\
(\mathrm{mV} / \mathrm{dec})\end{array}$ & $\begin{array}{c}\mathrm{I}_{\text {corr }} \\
\left(\mu \mathrm{A} / \mathrm{cm}^{2}\right)\end{array}$ & $\left(\mathrm{E}_{\mathrm{I}} \%\right)$ \\
\hline $\mathrm{HCl}$ & 1 & -470 & 217 & 1000 & - \\
\hline \multirow{5}{*}{$\mathrm{Q} \times 1$} & $10^{-4}$ & -460 & 169 & 147 & 85 \\
\cline { 2 - 6 } & $5 \times 10^{-5}$ & -465 & 179 & 232 & 77 \\
\cline { 2 - 6 } & $10^{-5}$ & -462 & 197 & 337 & 66 \\
\cline { 2 - 6 } & $5 \times 10^{-6}$ & -460 & 211 & 504 & 50 \\
\cline { 2 - 6 } & $10^{-6}$ & -461 & 215 & 581 & 42 \\
\hline \multirow{5}{*}{$\operatorname{Diam} 1$} & $10^{-3}$ & -458 & 200 & 238 & 76 \\
\cline { 2 - 6 } & $10^{-4}$ & -465 & 210 & 468 & 53 \\
\cline { 2 - 6 } & $5 \times 10^{-5}$ & -467 & 206 & 518 & 48 \\
\cline { 2 - 6 } & $10^{-5}$ & -466 & 209 & 584 & 42 \\
\cline { 2 - 6 } & $10^{-6}$ & -461 & 215 & 662 & 34 \\
\hline
\end{tabular}

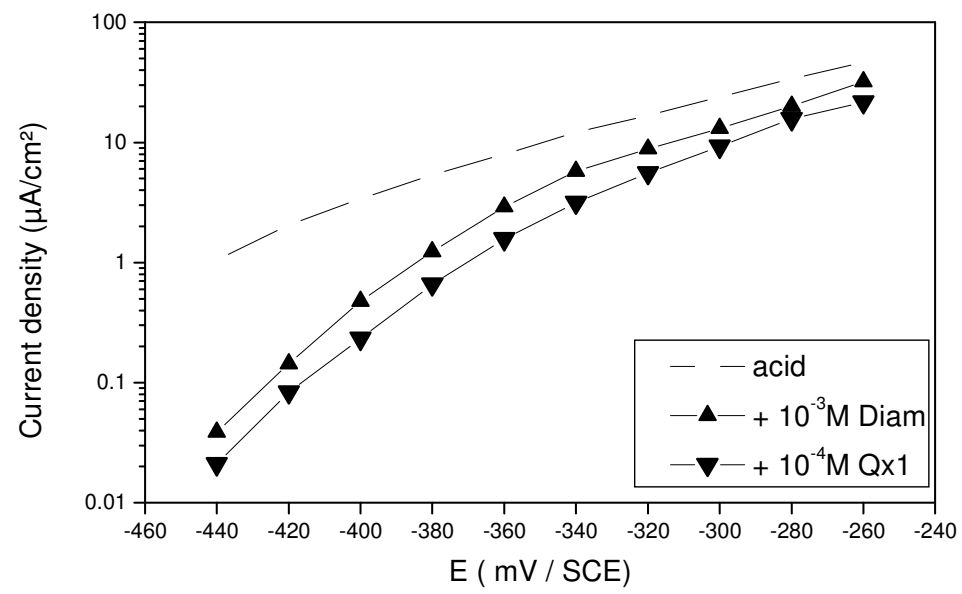

Figure 2. Polarisation curves of steel in $1 \mathrm{M} \mathrm{HCl}$ and added by $10^{-3} \mathrm{M}$ Diam and $10^{-4} \mathrm{M}$ Qx1.

As it is shown in Fig. 1 and Table 2, cathodic polarisation curves rise to parallel Tafel lines, indicating that the hydrogen evolution reaction is activation controlled. Thus, the presence of diamine and quinoxaline compounds does not affect the mechanism of this process. The addition of molecules tested causes a 
decrease of the current density. The values of corrosion potential $\left(\mathrm{E}_{\mathrm{corr}}\right)$ and cathodic Tafel slope $\left(b_{c}\right)$ remain almost constant upon the addition of inhibitor concentration. The results demonstrate that the hydrogen reduction is inhibited and that the inhibition efficiency increases with inhibitor concentration to attain $85 \%$ at $10^{-4} \mathrm{M}$ and $76 \%$ at $10^{-3} \mathrm{M}$ for Qx1 and Diam1, respectively.

The anodic curves obtained in Fig. 2 indicate that the inhibition mode of Diam1 and Qx1 does not depend upon electrode potential. The presence of Diam1 and Qx1 decreases the anodic current density versus potential characteristics. The anodic inhibitory action of Qx1 is better than that of Diam1. This result indicates that Qx1 and Diam1 act as mixed inhibitors.

\section{Electrochemical impedance spectroscopy (EIS)}

Electrochemical impedance spectroscopy (EIS) measurements have been carried out at $308 \mathrm{~K}$ in acidic solution with and without quinoxaline compound. The charge-transfer resistance $\left(R_{t}\right)$ values were calculated from the difference in impedance at lower and higher frequencies. The double layer capacitance $\left(\mathrm{C}_{\mathrm{dl}}\right)$ and the frequency at which the imaginary component of the impedance is maximal $\left(-Z_{\max }\right)$ were calculated from the equation (3) below:

$$
C_{d l}=\left(1 / \omega \cdot R_{t}\right)
$$

where $\omega=2 \pi f_{\max }$

The inhibition efficiency got from the charge transfer resistance is calculated by using equation (4):

$$
\mathrm{E}_{\mathrm{Z}}(\%)=100 .\left(1-\mathrm{R}_{\mathrm{t}} / \mathrm{R}_{\mathrm{t} / \mathrm{inh}}\right)
$$

where $R_{t}$ and $R_{t / i n h}$ are the charge transfer-resistance values with and without inhibitor, respectively.

Table 3. Impedance parameters for steel in $1 \mathrm{M} \mathrm{HCl}$ for various concentrations of $\mathrm{Q} \times 1$.

\begin{tabular}{|c|c|c|c|c|c|}
\hline & Concentration & $\mathrm{R}_{\mathrm{t}}\left(\Omega . \mathrm{cm}^{2}\right)$ & $\mathrm{f}_{\max }(\mathrm{Hz})$ & $\mathrm{C}_{\mathrm{dl}}\left(\mu \mathrm{F} / \mathrm{cm}^{2}\right)$ & $\mathrm{Ez} \%$ \\
\hline $\mathrm{HCl} 1 \mathrm{M}$ & $1 \mathrm{M}$ & 90 & 40 & 44.23 & - \\
\hline \multirow{3}{*}{ Qx1 } & $10^{-6} \mathrm{M}$ & 145 & 25 & 43.92 & 40 \\
\cline { 2 - 6 } & $10^{-5} \mathrm{M}$ & 230 & 15.82 & 43.76 & 61 \\
\cline { 2 - 6 } & $10^{-4} \mathrm{M}$ & 510 & 10 & 31.22 & 82 \\
\hline
\end{tabular}

The impedance parameters derived from these investigations at $\mathrm{E}_{\text {corr }}$ are presented in Table 3. As observed in Fig. 3, the impedance diagrams consist of one large capacitive loop. In fact, the presence of quinoxaline compounds enhances the value of $R_{t}$ in acidic solution, indicating a charge transfer process mainly controlling the corrosion of steel. Values of double layer capacitance decrease to the maximum extent in the presence of $Q \times 1$. This result is due to the 
adsorption of $\mathrm{Q} \times 1$ on the metal surface leading to the formation of film from acidic solution [32].

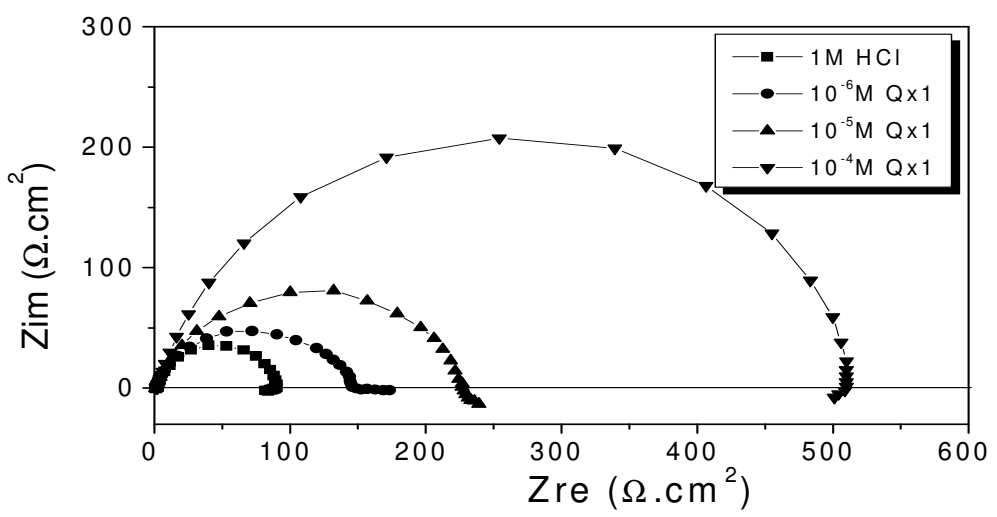

Figure 3. Nyquist plots of steel in $1 \mathrm{M} \mathrm{HCl}$ containing various concentrations of $\mathrm{Qx} 1$ at $\mathrm{E}_{\text {corr }}$.

In order to get more information about the action of Qx1 on the partial branches of corrosion behaviour of steel, EIS diagrams were recorded at cathodic ( -600 $\mathrm{mV})$ and anodic $(-300 \mathrm{mV})$ potentials. Table 4 shows the corresponding EIS parameters. We observed a noticeable decrease of $\mathrm{R}_{\mathrm{t}}$ in the anodic range due to the higher dissolution of steel in acid compared to those in cathodic and at $\mathrm{E}_{\text {corr }}$. But, a greater increase of $\mathrm{R}_{\mathrm{t}}$ is observed both in cathodic, $\mathrm{E}_{\text {corr }}$, and anodic potentials in inhibited acid than in free acid. The efficiencies obtained are 77, 82 and $73 \%$ at $-600 \mathrm{mV}, \mathrm{E}_{\text {corr }}$ and $-300 \mathrm{mV}$, respectively. These results confirm that $\mathrm{Q} \times 1$ adsorbs both on cathodic and anodic domains and therefore acts as a mixed type-inhibitor.

Table 4. EIS parameters obtained at cathodic $(-600 \mathrm{mV}), \mathrm{E}_{\text {corr }}$ and anodic $(-300 \mathrm{mV})$ potentials.

\begin{tabular}{|c|c|c|c|c|}
\hline & $\mathrm{R}_{\mathrm{t}}\left(\Omega \cdot \mathrm{cm}^{2}\right)$ & $\mathrm{f}_{\max }(\mathrm{Hz})$ & $\mathrm{C}_{\mathrm{dl}}\left(\mu \mathrm{F} / \mathrm{cm}^{2}\right)$ & $\mathrm{Ez} \%$ \\
\hline $1 \mathrm{M} \mathrm{HCl}$ at $-600 \mathrm{mV}$ & 33 & 158.2 & 30.50 & - \\
\hline$+10^{-4} \mathrm{M} \mathrm{Qx} 1$ at $-600 \mathrm{mV}$ & 141 & 25 & 45.17 & 77 \\
\hline $1 \mathrm{M} \mathrm{HCl}$ at $\mathrm{E}_{\text {corr }}$ & 90 & 40 & 44.23 & - \\
\hline$+10^{-4} \mathrm{M} \mathrm{Qx} 1$ at $\mathrm{E}_{\mathrm{corr}}$ & 510 & 10 & 31.22 & 82 \\
\hline $1 \mathrm{M} \mathrm{HCl}$ at $-300 \mathrm{mV}$ & 5.2 & 100 & 306.2 & - \\
\hline$+10^{-4} \mathrm{M} \mathrm{Qx} 1$ at $-300 \mathrm{mV}$ & 20 & 250 & 31.7 & 73 \\
\hline
\end{tabular}




\section{Effect of temperature}

The effect of temperature on the corrosion rate of steel in free acid and on addition of $10^{-4} \mathrm{M} \mathrm{Q} \times 1$ at 1 hour immersion period from 308 to $353 \mathrm{~K}$ is shown in Table 5.

Table 5. Effect of temperature on the steel corrosion in free acid and on addition of $10^{-4}$ $\mathrm{M}$ of $\mathrm{Q} \times 1$ at $1 \mathrm{~h}$ immersion period.

\begin{tabular}{|c|c|c|c|}
\cline { 2 - 4 } \multicolumn{1}{c|}{} & $1 \mathrm{M} \mathrm{HCl}$ & \multicolumn{2}{c|}{$1 \mathrm{M} \mathrm{HCl}+10^{-4} \mathrm{M}$ Qx1 } \\
\hline $\mathrm{T}(\mathrm{K})$ & $\mathrm{W}^{0}\left(\mathrm{mg} \cdot \mathrm{h}^{-1} \cdot \mathrm{cm}^{-2}\right)$ & $\mathrm{W}\left(\mathrm{mg} \cdot \mathrm{h}^{-1} \cdot \mathrm{cm}^{-2}\right)$ & $\mathrm{E}_{\mathrm{w}} \%$ \\
\hline 308 & 0.661 & 0.124 & 81 \\
\hline 313 & 0.858 & 0.215 & 75 \\
\hline 323 & 1.437 & 0.572 & 60 \\
\hline 333 & 2.725 & 1.506 & 45 \\
\hline 343 & 5.388 & 3.981 & 26 \\
\hline 353 & 10.649 & 7.978 & 25 \\
\hline
\end{tabular}

It is clear that the corrosion rate increased considerably with the rise of temperature for blank solution. In the presence of the tested molecules, the corrosion rate is highly reduced at moderate temperatures. We observed that the efficiency depends on the temperature and decreases with temperature up to $25 \%$ at $353 \mathrm{~K}$. This can be explained by the decrease of the strengh of the adsorption processes at elevated temperature, suggesting a physical adsorption mode.

The logarithm of the corrosion rate of steel $\mathrm{W}_{\text {corr }}$ can be represented as a straightline (Fig. 4) function of 1000/T (Arrhenius equation, equation 5), where $\mathrm{T}$ is the temperature in Kelvin:

$$
\mathrm{W}_{\text {corr }}=\mathrm{K} \exp \left(-\mathrm{E}_{\mathrm{a}} / \mathrm{RT}\right) \text { and } \mathrm{W}_{\text {corr }}^{0}=\mathrm{K}^{\prime} \exp \left(-\mathrm{E}_{\mathrm{a}}^{\prime} / \mathrm{RT}\right)
$$

$\mathrm{E}_{\mathrm{a}}{ }^{\prime}=83.1$ and $\mathrm{E}_{\mathrm{a}}=57.8 \mathrm{~kJ} / \mathrm{mol}$ are the activation energy with and without Qx1, respectively.

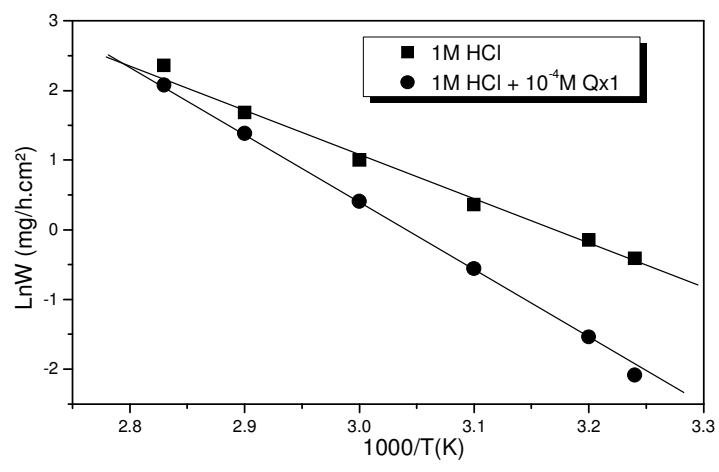

Figure 4. Arrhenius plots of steel in $1 \mathrm{M} \mathrm{HCl}$ in the absence and presence of $10^{-4} \mathrm{M}$ $\mathrm{Q} \times 1$. 
It is observed that $E_{a}$ increases in the presence of inhibitor, which indicates poor performance of $\mathrm{Q} \times 1$ at higher temperatures. This increase of activation energy is generally interpreted as an electrostatic adsorption process of inhibitor on the steel surface $[33,34]$.

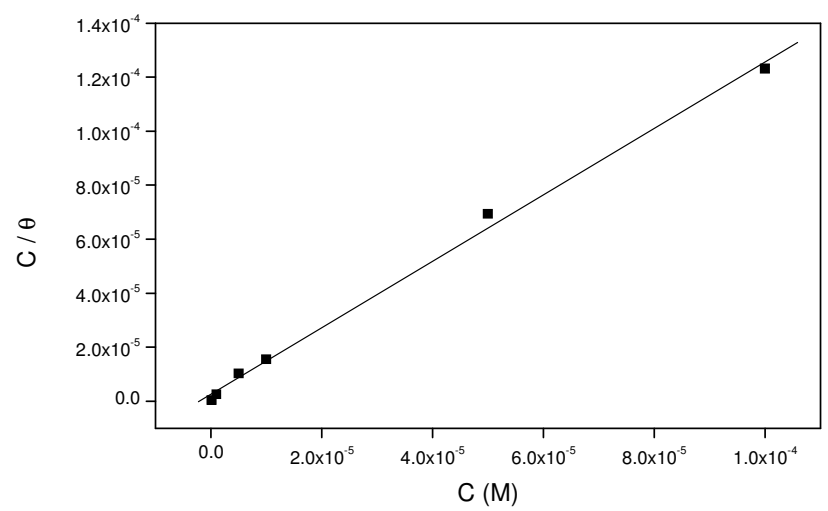

Figure 5. Langmuir isotherm adsorption of quinoxaline on steel in $1 \mathrm{M} \mathrm{HCl}$.

\section{Adsorption isotherm}

Fig. 5 illustrates the dependence of the fraction of the concentration and the effective surface covered $\mathrm{C} / \theta$ as a function of the concentration of the quinoxalines. $\theta$ is the ratio $\mathrm{E} / 100$. The obtained plot is linear with a slope equal to 1.23 near to unity, showing an adsorption on the steel surface electrode according to the Langmuir [35] isotherm (equation 6):

$$
\frac{C}{\theta}=C+\frac{1}{K}
$$

with $K=\frac{1}{55.55} \exp \left(-\frac{\Delta G_{a d s}^{0}}{R T}\right) . \mathrm{K}$ is the equilibrium constant leading to the standard free energy of adsorption, $\Delta \mathrm{G}_{\mathrm{ads}}$.

The values obtained for the equilibrium constant $\mathrm{K}$ and $\Delta \mathrm{G}_{\text {ads }}^{\circ}$ are 354862 and $43.04 \mathrm{~kJ} / \mathrm{mol}$, respectively. The negative value of $\Delta \mathrm{G}_{\text {ads }}^{\circ}$ indicates that $\mathrm{Qx} 1$ is strongly adsorbed on the steel surface [36]. The nature of the adsorption process can be clarified further if the heat of adsorption $\Delta \mathrm{H}_{\text {ads }}^{\circ}$ value is known. It has been shown [37] that for $\Delta \mathrm{H}_{\text {ads }}^{\circ}<10 \mathrm{~kJ} / \mathrm{mol}$ the adsorption is most probably physical in character, while for $\Delta \mathrm{H}_{\text {ads }}^{\circ}>10 \mathrm{~kJ} / \mathrm{mol}$ chemisorption is expected. The determination of $\Delta \mathrm{H}_{\text {ads }}^{\circ}$ may be deduced from the Langmuir adsorption expression below (equation 7) [35]:

$$
\ln \frac{\theta}{1-\theta}=\ln A+\ln C-\frac{\Delta H_{a d s}^{\circ}}{R T}
$$




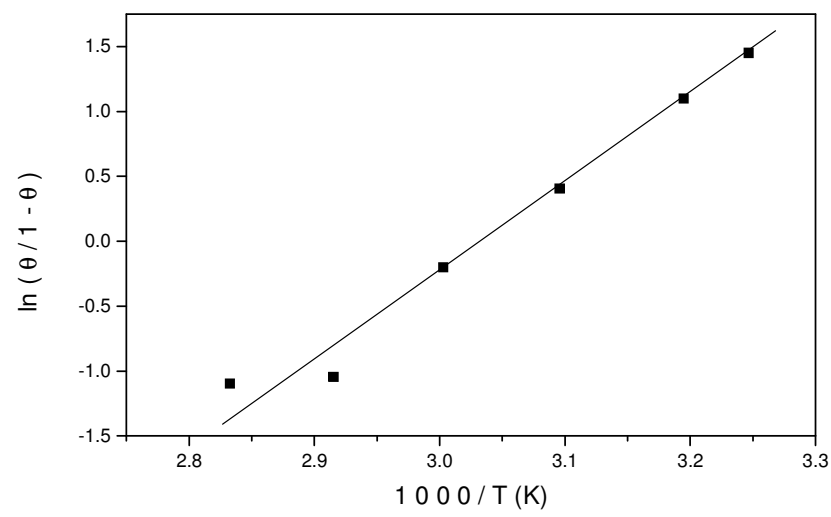

Figure 6. Heat of adsorption determination from the plot of $\ln (\theta / 1-\theta)$ vs. 1000/T for $10^{-4} \mathrm{M}$ Qx1.

The slope of the straight line obtained in Fig. 6 equals to $-\Delta H_{\text {ads }}^{\circ} / \mathrm{R}$. The heat of adsorption obtained is $-54.86 \mathrm{~kJ} / \mathrm{mol}$. The negative value obtained shows that the adsorption is an exothermic phenomenon. Also, the relatively low $\Delta \mathrm{H}_{\text {ads }}^{\circ}$ verifies the physical adsorption character of the adsorption. The adsorption entropy $\Delta \mathrm{S}_{\text {ads }}^{\circ}$ deduced is $-39.7 \mathrm{~J} / \mathrm{mol}$. The negative value of $\Delta S^{\circ}$ means that the adsorption process is accompanied by a decrease in entropy and a disordered layer of Qx1 molecules takes place on the steel surface. The inhibitory action of Qx1 may be explained by an intramolecular synergistic effect between secondary diamine and the rest of molecule.

\section{Conclusion}

- The quinoxaline studied Qx1 and Diam 1 are good inhibitors for steel in $1 \mathrm{M}$ $\mathrm{HCl}$.

- The inhibition efficiency of Qx1 increases with the increase of the concentration up to $85 \%$ at $10^{-4} \mathrm{M}$.

- Qx1 and Diam1 act as mixed-type inhibitors without modifying the mechanism of hydrogen evolution.

- The inhibition efficiency of Qx1 decreases with increase in temperature.

- Qx1 adsorbs on the steel surface according to the Langmuir adsorption isotherm.

\section{References}

1. H. Shokry, M. Yuasa, I. Sekine, R.M. Issa, H.Y. El-baradie, G.K. Gomma, Corros. Sci. 40 (1998) 2173. 10.1016/S0010-938X(98)00102-4

2. Sk.A. Ali, M.T. Saeed, Polymer 42 (2001) $2785 . \quad 10.1016 /$ S00323861(00)00665-0

3. A. Ouchrif, M. Zegmout, B. Hammouti, A. Dafali, M. Benkaddour, A. Ramdani, S. Elkadiri, Prog. Org. Coat. $53 \quad$ (2005) 292. 10.1016/j.porgcoat.2005.02.010 
4. M. Bouklah, B. Hammouti, A. Aouniti, M. Benkaddour, A. Bouyanzer, Appl. Surf. Sci. 252 (2006) 6236. 10.1016/j.apsusc.2005.08.026

5. B. Hammouti, A. Aouniti, M. Taleb, M. Brighli, S. Kertit, Corrosion 51 (1995) 411.

6. R. Salghi, B. Hammouti, S. Kertit, Bull. Electrochem.13 (1997) 399.

7. M. Zerfaoui, H. Oudda, B. Hammouti, M. Benkaddour, S. Kertit, M. Zertoubi, M. Azzi, M. Taleb, Revue de métallurgie 99 (2002) 1105. 10.1051/metal:2002156

8. D. Bouzidi, S. Kertit, B. Hammouti, M. Brighli, J. Electrochem. Soc. India 46 (1997) 23.

9. R. Salghi, B. Hammouti, A. Aouniti, M. Berrabah, S. Kertit, J. Electrochem. Soc. India 49 (2000) 40.

10. R. Salghi, L. Bazzi, E. Ait Addi, B. Hammouti, Transactions of the SAEST 38 (2003) 127.

11. M. Zerfaoui, B. Hammouti, H. Oudda, M. Benkaddour, Prog. Org. Coat. 51 (2004) 134. 10.1016/j.porgcoat.2004.05.005

12. F. Touhami, A. Aouniti, S. Kertit, Y. Abed, B. Hammouti, A. Ramdani, K. El- Kacemi, Corros. Sci. 42 (2000) 929. 10.1016/S0010-938X(99)00123-7

13. A. Chetouani, M. Daoudi, B. Hammouti, T. Ben Hadda, M. Benkaddour, Corros. Sci. 48 (2006) 2987. 10.1016/j.corsci.2005.10.011

14. K. Tebbji, I. Bouabdellah, A. Aouniti, B. Hammouti, H. Oudda, M. Benkaddour, A. Ramdani, Mater. Lett. $61 \quad$ (2007) 799. 10.1016/j.matlet.2006.05.063

15. L. Herrag, A. Chetouani, S. Elkadiri, B. Hammouti, A. Aouniti, Port. Electrochim. Acta 26 (2008) 211. 10.4152/pea.200802211

16. K. Laarej, M. Bouachrine, S. Radi, S. Kertit, B. Hammouti, E-Journal of Chemistry 7 (2010) 419.

17. R. Salghi, L. Bazzi, B. Hammouti, E. Zine, S. Kertit, S. El Issami, E. Ait Eddi, Bull. Electrochem. 17 (2001) 429.

18. B. Zerga, A. Attayibat, M. Sfaira, M. Taleb, B. Hammouti, M. Ebn Touhami, S. Radi, Z. Rais, J. Appl. Electrochem. 40 (2010) 1575. 10.1007/s10800-010-0164-0

19. Y. Abed, B. Hammouti, S. Kertit, K. El Kacemi, A. Mansri, Bull. Electrochem. 17 (2001) 105.

20. O. Krim, A. Elidrissi, B. Hammouti, A. Ouslim, M. Benkaddour, Chem. Eng. Comm. 196 (2009) 1536. 10.1080/00986440903155451

21. A. Chetouani, K. Medjahed, K.E. Benabadji, B. Hammouti, S. Kertit, A. Mansri, Prog. Org. Coat. 46 (2003) 312. 10.1016/S0300-9440(03)00019-5

22. A. Chetouani, K. Medjahed, K.E. Sid-Lakhdar, B. Hammouti, M. Benkaddour, A. Mansri, Corros. Sci. $46 \quad$ (2004) 2421. 10.1016/j.corsci.2004.01.020

23. M. Bouklah, A. Attayibat, B. Hammouti, A. Ramdani, S. Radi, M. Benkaddour, Appl. Surf. Sci. 240 (2004) 341. 10.1016/j.apsusc.2004.07.001

24. M. Benabdellah, R. Touzani, A. Aouniti, A. Dafali, S. Elkadiri, B. Hammouti, M. Benkaddour, Phys. Chem. News 37 (2007) 63.

25. M. Benabdellah, K. Tebbji, B. Hammouti, R. Touzani, A. Aouniti, A. Dafali, S. El Kadiri, Phys. Chem. News 43 (2008) 115. 
26. A. Zarrouk, A Dafali, B. Hammouti, H. Zarrok, S. Boukhris, M. Zertoubi, Int. J. Electrochem. Sci. 5 (2010) 46.

27. I. El Ouali, B. Hammouti, A. Aouniti, Y. Ramli, M. Azougagh, E.M. Essassi, M. Bouachrine, J. Mater. Environ. Sci. 1 (2010) 1.

28. H. Gali-Muhtasib, M. Sidani, F. Geara, A-D. Mona, J. Al-Hmaira, M.J. Haddadin, G. Zaatari, Int. J. Oncol. 24 (2004) 1121.

29. S. Piras, M. Loriga, G. Paglietti, Il Farmaco 59 (2004) 185. 10.1016/j.farmac.2003.11.014

30. A. Jaso, B. Zarranz, I. Aldana, A. Monge, Tubérculos 38 (2003) 791.

31. A. Carta, M. Loriga, G. Paglietti, A. Mattana, P.L. Fiori, P. Mollicotti, L. Sechi, S. Zanetti, Eur. J. Med. Chem. 39 (2004) 195. 10.1016/j.ejmech.2003.11.008

32. F. Bentiss, M. Lagrenée, M. Traisnel, J.C. Hornez, Corros. Sci. 41 (1999) 789. 10.1016/S0010-938X(98)00153-X

33. A. Popova, E. Sokolova, S. Raicheva, M. Christov, Corros. Sci. 45 (2003) 33. $10.1016 / \mathrm{S} 0010-938 \mathrm{X}(02) 00072-0$

34. T. Szauer, A. Brandt, Electrochim. Acta 26 (1981) 1209. 10.1016/00134686(81)85101-8

35. I. Langmuir, J. Am. Chem. Soc. 39 (1947) 1848. 10.1021/ja02254a006

36. Y.A. El-Awady, A.I. Ahmed, J. Ind. Chem. 24A (1985) 601.

37. A.E. Stoyanova, E.I. Sokolova, S.N. Raicheva, Corros. Sci. 39 (1997) 1595. 10.1016/S0010-938X(97)00063-2 